\title{
Where to Protect? Prioritization and the Responsibility to Protect
} Luke Glanville • and James Pattison

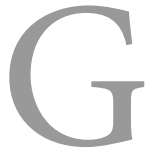

iven the multiple threats of atrocities in the world at any given time, where should states direct their attention and resources? In this contribution, we argue that despite the rich and extensive literature on the responsibility to protect (RtoP) that has emerged over the past two decades, little thought has been given to how states and other international actors should prioritize when faced with multiple situations of ongoing and potential mass atrocities. This failure to address the question of where to protect renders RtoP an "imperfect duty," with the effect of fueling criticisms of the selective application of international responsibilities for protection and leaving vulnerable populations unable to effectively claim their rights to protection.

Accordingly, this contribution has two central aims. The first is to highlight the importance of questions of prioritization for RtoP. The second is to delineate some of the central issues involved in assessing the issue of prioritization, thereby setting an agenda for future discussions.

\section{The Importance and Neglect of Prioritization}

"How do I weigh tens of thousands who've been killed in Syria versus the tens of thousands who are currently being killed in the Congo?" asked U.S. president

Luke Glanville is associate professor in the Department of International Relations at the Australian National University, located in Canberra, Australia.

James Pattison is professor of politics at the University of Manchester, located in Manchester, England.

Ethics \& International Affairs, 35, no. 2 (2021), pp. 213-225.

(c) The Author(s), 2021. Published by Cambridge University Press on behalf of the Carnegie Council for Ethics in International Affairs. This is an Open Access article, distributed under the terms of the Creative Commons Attribution licence (http://creativecommons.org/licenses/by/4.o/), which permits unrestricted re-use, distribution, and reproduction in any medium, provided the original work is properly cited.

doi:10.1017/So892679421000198 
Barack Obama in 2013. ${ }^{1}$ Although some commentators suggested that Obama was seeking to deflect the pressure to do more to protect civilians in Syria, ${ }^{2}$ his question nevertheless highlights the absence of clear guidance for thinking about how to prioritize mass atrocity situations. Under RtoP, which is the leading framework for responding to mass atrocities, states have not only the responsibility to redress potential and ongoing mass atrocities within their own borders (under RtoP's pillar one) but also the responsibility to assist other states in their efforts to tackle mass atrocities within their borders (under pillar two) and to take timely and decisive action to provide protection when these host states are failing to do so (under pillar three). Yet despite more than ten annual reports by United Nations secretaries-general on how to understand and implement the various responsibilities under RtoP and dozens of books and hundreds of articles on RtoP, as well as a specialist journal, the Global Responsibility to Protect, the issue of how to prioritize among multiple atrocity situations has been almost completely overlooked. ${ }^{3}$

In the literature on international ethics, scholars have paid significant attention to the allocation of responsibilities among states to address single situations of concern, not only with respect to the issue of military intervention in response to mass atrocities but also with respect to other issue areas such as climate change and forced displacement. ${ }^{4}$ In the case of military intervention, this is often framed in terms of the question, Who should intervene? ${ }^{5}$ However, these accounts overlook the reality that states and other actors are usually confronted with multiple situations of concern at any given time, including multiple situations of threatened or ongoing mass atrocities. ${ }^{6}$ For instance, at the time of writing, the Global Centre for the Responsibility to Protect identifies twenty "populations at risk" of mass atrocities. ${ }^{7}$ Given various feasibility constraints, including the material and political limits to costly international action, and, more fundamentally, the difficulty of effectively resolving all concurrent atrocity situations of concern, it is vital to consider how to prioritize among multiple mass atrocity situations.

A useful way of conceptualizing the task at hand is to consider how RtoP entails an "imperfect duty." In contrast to "perfect duties," which specify what an actor must do and when and for whom-such as a duty to always refrain from unjustly harming all other actors-imperfect duties are indeterminate in one or more ways. Much of the existing literature in international ethics holds that states have responsibilities to address mass atrocities, stemming either from duties of justice (defended by cosmopolitans) ${ }^{8}$ or duties of humanity (defended by some renowned noncosmopolitans). ${ }^{9}$ Yet, even if we take as a given that states are duty bound to 
respond to mass atrocities beyond their borders, when we consider these duties more closely we quickly discern that they are imperfect duties. They are imperfect in multiple respects. ${ }^{10}$ One sense of imperfection relates to the question of allocation mentioned earlier. That is, it is often unclear which state or states (other than the host state) bear the duty to help protect a population at risk of atrocities in a given instance. The duty to act, from the perspective of any particular state, is thus imperfect. Thoughtful scholarship on how duties should be allocated among states has sought to address this imperfection and to explain how the duty might be made more "perfect" in that regard. ${ }^{11}$ A second sense of imperfection, which has been largely neglected, relates to the question of prioritization. That is, it is often unclear which threatened or ongoing mass atrocities a state ought to seek to address beyond its borders in a given instance. The duty of a given state to respond to any particular situation of concern is thus imperfect. There is a need to work toward perfecting the duty to protect in this sense too, by clarifying how states should prioritize among multiple situations.

In the absence of clear principles and frameworks for prioritization, the efforts of states to implement the second and third pillars of RtoP are commonly subjected to the charge of selectivity. This accusation of selectivity was levelled against several of the humanitarian interventions of the $1990 .^{12}$ In the supplementary volume that accompanies The Responsibility to Protect report of the International Commission on Intervention and State Sovereignty in 2001, Thomas Weiss and Don Hubert summarize this oft-heard critique as follows: "Why act in Kosovo but not in Rwanda? Why protect the Kurds in northern Iraq but not in Turkey? Why emphasize a crisis in Somalia and not a three-decade-long emergency in neighbouring Sudan? Why intervene against smaller states but ignore Russian actions in Chechnya?"13 One of the aims of the RtoP doctrine has been to overcome this selectivity objection by encouraging states to more consistently respond to the threat and perpetration of atrocities around the world. Nevertheless, responses to atrocities in the RtoP era have continued to be subject to allegations of selectivity, most notably in commentary contrasting the intervention in Libya in 2011 with the absence of similarly robust intervention in Syria in the years that followed. ${ }^{14}$

Those who have addressed the selectivity objection have typically made two points. First, different cases of mass atrocities warrant different responses due to their differing political, strategic, legal, and other contexts. Whereas military intervention might stand a good chance of ending atrocities in one situation, in 
another it may be more likely to exacerbate the suffering. Far from being morally objectionable, in such instances abstaining from intervention is morally required. This is the answer that was commonly given to such questions as, Why Kosovo but not Chechnya? Second, the perfect should not be the enemy of the good. Even if intervention would be justifiable in response to multiple situations of concern, it is not wrong to intervene in just one situation. Just because one does not intervene everywhere that there are mass atrocities does not mean that it is wrong to intervene somewhere that they are occurring. ${ }^{15}$

These two replies take some of the force out of the selectivity objection. However, there is an important-and largely overlooked—sense in which it may be wrong to intervene in response to one situation of mass atrocities and not another: In some instances, there may be ethical reasons for prioritizing responding to one situation but not another, or for striving to respond to both. Thus, rather than comparing Kosovo to Chechnya (where humanitarian intervention in the latter case would have very likely been unsuccessful), a more pertinent example may be justifying intervention in Somalia but not Bosnia in 1992; or, more recently, explaining the forceful response to the use of chemical weapons by the Bashar al-Assad regime in Syria in 2017 and 2018 compared to the nearly nonexistent response to Myanmar's ethnic cleansing of the Rohingya in the same period.

Certainly, if the international community is responding robustly and effectively to all mass atrocity situations at a given moment, then questions of prioritization become, on the face of it, less pressing. Alex Bellamy and Edward Luck argue that over the past decade, we have seen the emergence of "habits of protection," whereby the international community has come to routinely respond to, rather than ignore, mass atrocities. As they argue, "In assuming an almost habitual quality, collective international action to support the protection of populations from atrocity crimes has become 'the norm.' Not only has complete failure to act become rare, so too have entirely tokenistic responses." ${ }^{16}$ Nevertheless, they also argue that responses to mass atrocities have in numerous instances continued to be insufficiently robust and effective, and some responses have been plainly lamentable, as we have seen most notably in Syria and Myanmar. Thus, even if recent years have seen the emergence of significant habits of protection, states and other international actors still need to decide how to prioritize their responses. Even if all mass atrocity events are subject to some form of response, some are likely to receive-and indeed do presently receive-a stronger response than others in terms of the deployment of attention and resources. It is extremely difficult 
to maintain an effective response to more than a small number of major crisis situations. Prioritization is necessary, then, and some prioritization decisions are more justifiable than others.

Moreover, the habits of protection of which Bellamy and Luck write could be at risk in an emerging postliberal order where there are, on the one hand, fewer states willing to respond to mass atrocity situations and, on the other, additional atrocity situations arising due to increasing nationalist xenophobia and enmity, decreasing commitment to multilateralism, and eroding liberal humanitarian norms. Already the rise of nationalist rhetoric and the increasingly inward-looking turn by the United States and other states have led to a shift toward prioritizing domestic and self-interested concerns, resulting in fewer resources being made available to spend on tackling global challenges, including threats and perpetrations of mass atrocities. This is on the back of neoliberal austerity measures and significant cuts to the budgets of foreign ministries in recent years. Bellamy and Luck accept that "in the near term the implementation of $\mathrm{R}_{2} \mathrm{P}$ will not be able to call upon significant new resources.... [M] ajor efforts to address atrocities will have to draw upon resources dedicated to other fields of work." ${ }^{17}$ The financial impact of the COVID-19 pandemic seems likely to exacerbate this situation significantly, rendering the challenges raised by the opportunity costs that attend prioritization decisions even more acute. Indeed, leading RtoP figures (such as Karen Smith, the current UN special adviser of the secretary-general on the responsibility to protect, and also the three previous special advisers on the RtoP) warn that the pandemic is likely to significantly increase the risk to already vulnerable populations as, for instance, hate crimes increase, those fleeing atrocities find even stricter border restrictions, severe economic hardships serve as a "trigger factor" for mass atrocities, and international attention and resources that in previous years may have been given to preventing and ending such atrocities are redirected elsewhere. ${ }^{18}$

\section{TOWARD AN ANSWER}

How then should we go about answering the question of where to protect? To begin, it is worth emphasizing that the task at hand should not be conceived solely in terms of prioritizing which existing mass atrocity situation to react to via, for example, military intervention or the imposition of economic sanctions. Oftentimes, states will be in a position to help prevent the outbreak of mass atrocities in the first place via, for example, the provision of capacity-building measures 
or the deployment of peacekeepers. These two categories of reaction and prevention are well known in RtoP discussions. A third is often less highlighted-what we call "amelioration." Amelioration measures do not directly aim to tackle ongoing atrocities or prevent future ones, but rather aim to lessen the suffering of people caught up in mass atrocity situations through, for example, the provision of humanitarian relief or refuge. ${ }^{19}$ Any useful answer to the question of where to protect, we suggest, needs to account for each of these three domains of protection: prevention, reaction, and amelioration. We will return to these three domains shortly. Let us first consider what an answer to the question of where to protect might look like.

\section{A Basic Maximization Model}

Helpful accounts of the ethics of priority setting in the face of scarce resources can be found in other research fields. Literature on medical ethics provides welldeveloped prioritization principles and models to guide the distribution of limited health resources. ${ }^{20}$ Research on the ethics of humanitarian aid helpfully considers a range of frameworks for how nongovernmental organizations should best deploy their resources in the face of multiple situations of concern. ${ }^{21}$ A body of literature has begun to emerge on the difficult question of how to decide which among many refugees to resettle. ${ }^{22}$ Particularly prominent among the various strands of resource-prioritization discussions in recent years has been the effective altruism movement, which suggests that when it comes to charitable giving people should donate money in the most effective way, using their limited resources to save the most lives. ${ }^{23}$

A useful principle that is highlighted in a range of fields, most obviously in the study of effective altruism, is the principle of maximization. Indeed, the most obvious and straightforward framework for prioritizing where to protect is what we call the "basic maximization model." This model requires that states prioritize responding to threatened and ongoing atrocities in places where they seem likely to save the largest number of lives-or perhaps, in the terms of medical ethics, the largest number of "quality-adjusted life years" (QALYs). Application of the basic maximization model involves consideration of (1) the likely severity of the atrocities (which concerns the number of individuals affected and the severity of the situation they face); (2) the likelihood of making a positive impact (which concerns the possibility of contributing to protection via the application of pillar two or pillar three measures); (3) the magnitude of any potential positive impact; and (4) the potential costs that may be borne by either those doing the protecting 
or those they hope to protect (such as the unintended but foreseeable casualties of military intervention). To inform these assessments, it helps to draw on the notion of "neglectedness" proposed by effective altruists, which highlights the need to consider how others will act and whether they will likely attend to or neglect particular situations of concern. ${ }^{24}$ Thus, if certain states are making a substantial effort to address mass atrocities in one situation, it may be better for other potential responders to focus their efforts elsewhere, so as to help maximize the overall number of lives saved.

\section{Atrocity-Specific Considerations}

The basic maximization model is a valuable starting point. The idea of focusing attention and resources in places where there is the possibility of having the greatest positive impact seems attractive. However, this answer to the question of where to protect is incomplete. A more comprehensive response needs to take into account further moral considerations. It helps here to distinguish between "atrocity-specific" and "response-specific" considerations. Atrocity-specific considerations concern the features of the mass atrocities that render them in most need of attention. We have already noted one atrocity-specific consideration: the severity of the atrocities. But there are others that are not captured by the basic maximization model. These include the urgency of the situation. For instance, is it more important to tackle a crisis where an immediate response is required or a situation where larger numbers of people may die over a longer period of time? Recall the comparison mentioned above between the grave crisis in Somalia and the long-standing emergency in Sudan in the 1990s. Compare, similarly, the sudden threat of atrocities against civilians opposing the rule of Libyan leader Muammar Qaddafi in early 2011 and the slow ethnic cleansing of several minority groups in Myanmar before, during, and after the emergence of the perilous Libyan situation. Other potential atrocity-specific considerations to evaluate include whether one should prioritize atrocity situations for which one bears a degree of culpability. For instance, should those states that invaded Iraq in 2003, and thus contributed to the instability that has engulfed the region in the years since, prioritize responding to atrocities that emerge in that region rather than in others where they may be less culpable but likely able to help save more lives?

\section{Response-Specific Considerations}

Response-specific considerations concern the features of the responses that states might issue to mass atrocities. The most obvious is the likely effectiveness of the 
response, judged in terms of its success in protecting people from violence and suffering. But, again, there are important noninstrumental considerations that might warrant our attention, such as whether we should prefer measures that, in the process of averting harm also avoid doing harm to innocent civilians, even if they will be less effective in terms of total numbers of lives saved. ${ }^{25}$ For instance, does the potential for military intervention and economic sanctions to do harm to innocents mean that they should be disfavored? Also relevant here are the broader effects of a particular response, such as whether, in the process of saving some lives, it risks undermining the fragile and valuable consensus on RtoP that currently exists, with the likely effect of impeding the protection of other lives in the future. For instance, the aftermath of the response to threats of atrocities in Libya suggests that military intervention, even when authorized by the UN Security Council, risks generating controversy and provoking backlash that can result in weakened support for RtoP-or at least weakened support for RtoP's most coercive and interventionist measures under pillar three. ${ }^{26}$ This is not necessarily a decisive consideration. In certain instances, urgent need for action may outweigh any potential negative effects on the RtoP consensus. But such negative effects must nevertheless be taken into account when thinking about how to prioritize.

\section{Prioritizing within, across, and beyond Protection Domains}

To make some further headway, it is important to distinguish between three types of prioritization dilemmas, which relate to the different domains of engagement with mass atrocities noted above (prevention, reaction, and amelioration). The first type involves prioritization decisions that need to be made within each of the particular domains. For instance, within the reaction domain, how should states weigh the need to devote attention and resources to respond to atrocities being perpetrated in Cameroon against the need to do the same in Myanmar?

The second type of dilemma involves concerns that cut across the three domains. This type entails assessing the atrocity-specific and response-specific considerations across the range of RtoP responses. For instance, a dilemma may involve weighing the deployment of peacekeepers to prevent the renewal of mass atrocities in the Central African Republic against a large-scale diplomatic effort to react to ongoing atrocities in Ethiopia and also against a substantial effort to provide relief and refuge to some of the millions of civilians impacted by atrocities in Syria over the past decade. 
The third type involves concerns that go beyond the domain of the dilemma itself. This type entails the need to consider how the responsibility to prevent, react to, and ameliorate the effects of mass atrocities ought to be weighed against other global responsibilities, such as those concerning global poverty, global health, and climate change. This type of dilemma requires assessing, for instance, whether the attention and resources deployed in the diplomatic, military, and economic effort made to address mass atrocities in Syria would have been better used to promote global health, such as by better resourcing international efforts to combat malaria. In turn, the third dilemma requires the development of a more holistic view of international responsibilities and the place of RtoP within them. This also may raise further response-specific considerations that need to be evaluated but that are not encapsulated by a basic maximization model, including whether it is more important to tackle intentional violations of basic human rights, such as the perpetration of mass atrocities, than to address unintentional deaths from other causes, such as preventable diseases. ${ }^{27}$

\section{Where to Protect?}

What does this all mean in practice? We doubt that it would be plausible to draw strong conclusions about whether certain mass atrocity situations should always be prioritized. Much will depend on the features of specific situations, such as the severity of the violence and suffering, the likely impact of any response, the degree to which the response risks doing harm, and the broader consequences of action (and also inaction). ${ }^{28}$ Notwithstanding, we can offer three tentative suggestions.

First, reactive measures, particularly those that are most coercive-sanctions and military intervention-are often treated as the default response by scholars and politicians. However, while the application of such measures is often interpreted as demonstrating an especially significant commitment to upholding the RtoP norm, these measures tend to be accompanied by high risks and high costs, can undermine political consensus, are often limited in effectiveness at saving lives, and can sometimes worsen the severity and prolong the duration of mass atrocities. ${ }^{29}$ Particular care needs to be taken when contemplating a reactive response that carries a serious risk of doing more harm than good. Thus, it might often be preferable to prioritize crises that do not require sanctions or military intervention. 
Second, and related to this point, comparing the domains of reaction and amelioration, it seems likely that the provision of humanitarian relief and refuge, where feasible, should usually be favored, given that such ameliorative responses can typically save many lives more cheaply and with lower risk of doing harm and exacerbating suffering than reactive responses. Consequently, it might often be preferable to prioritize crises where these measures are a feasible response.

Third, if we look beyond mass atrocities, we may often find that the need to tackle situations of poor global health and global poverty is more pressing than tackling mass atrocity situations, given the sheer number of lives at stake from preventable disease and impoverishment and the magnitude of the impact that measures to address disease and poverty can provide. ${ }^{30}$ Accordingly, although atrocity prevention, response, and amelioration are valuable objectives, it might still be better to prioritize allocating resources elsewhere.

These three suggestions concern how states should ideally prioritize. But, of course, they may often be willing to engage only in certain forms of response and not others. The provision of relief and refuge to people displaced by mass atrocities, for instance, will be unpalatable to certain states, even if this is how they should ideally prioritize. Those same states may nevertheless be inclined to seek to bring to an end an intractable mass atrocity situation by intervening militarily, at substantial cost to themselves, even though it seems clear that their resources could be more effectively directed toward prevention or amelioration efforts elsewhere. Such a course of action, while seemingly suboptimal, may still be justified. ${ }^{31}$ As those responding to the selectivity objection argue, it is better to do something rather than nothing. Sometimes decision-makers will face significant constraints preventing them from doing more or from acting differently, such as a parliament that refuses to endorse spending on the most optimal measures or an international organization that does not authorize appropriate action. In the postliberal order, if some of the more pessimistic scenarios that commentators describe end up materializing, ${ }^{32}$ such constraints could become greater still, as domestic publics sanction fewer types of responses and UN Security Council members refuse to authorize almost any action aimed at protecting people from mass atrocities. In this regard, suboptimal prioritization might sometimes be permissible.

But if the failure to rightly prioritize among the multiple situations of concern and multiple possible means of preventing, reacting to, or ameliorating the suffering that attends such situations proceeds simply from decision-makers' lack of 
imagination, carelessness, or unwillingness to do what they can, they should be rightly criticized for protecting suboptimally. Although doing something is better than nothing, decision-makers should, wherever possible, take seriously their responsibility to consider where to protect.

\section{NOTES}

${ }^{1}$ Barack Obama, "Barack Obama Is Not Pleased: The President on His Enemies, the Media, and the Future of Football," interview by Franklin Foer and Chris Hughes, New Republic, January 27, 2013.

${ }^{2}$ Fred Hiatt, "Obama's Syria Achievement," Opinions, Washington Post, September 6, 2015.

${ }^{3}$ For instance, this is not addressed in several recent notable books on RtoP, including Alex J. Bellamy and Edward C. Luck, The Responsibility to Protect: From Promise to Practice (Oxford: Oxford University Press, 2018); Cecilia Jacob and Martin Mennecke, eds., Implementing the Responsibility to Protect: A Future Agenda (London: Routledge, 2020); Aidan Hehir, Hollow Norms and the Responsibility to Protect (Basingstoke, U.K.: Palgrave Macmillan, 2019); Yasmine Nahlawi, The Responsibility to Protect in Libya and Syria: Mass Atrocities, Human Protection, and International Law (London: Routledge, 2020); and Serena K. Sharma and Jennifer M. Welsh, eds., The Responsibility to Prevent: Overcoming the Challenges of Atrocity Prevention (Oxford: Oxford University Press, 2015).

${ }^{4}$ See, for instance, James Pattison, Humanitarian Intervention and the Responsibility to Protect: Who Should Intervene? (Oxford: Oxford University Press, 2010); Heather Roff, Global Justice, Kant and the Responsibility to Protect: A Provisional Duty (London: Routledge, 2014); Simon Caney, "Climate Change and the Duties of the Advantaged," Critical Review of International Social and Political Philosophy 13, no. 1 (2010), pp. 203-28; Matthew J. Gibney, "Refugees and Justice between States," European Journal of Political Theory 14, no. 4 (2015), pp. 448-63; and Serena Parekh, No Refuge: Ethics and the Global Refugee Crisis (Oxford: Oxford University Press, 2020).

${ }^{5}$ In addition to Pattison, Humanitarian Intervention and the Responsibility to Protect, see Toni Erskine, "Moral Agents of Protection and Supplementary Responsibilities to Protect," in Alex J. Bellamy and Tim Dunne, eds., The Oxford Handbook of the Responsibility to Protect (Oxford: Oxford University Press, 2016), pp. 167-86; Cécile Fabre, Cosmopolitan War (Oxford: Oxford University Press, 2012), pp. 187-92; Heather Roff, "Response to Pattison: Whose Responsibility to Protect?," Journal of Military Ethics 8, no. 1 (2009), pp. 79-85; Kok-Chor Tan, "The Duty to Protect," in Terry Nardin and Melissa S. Williams, eds., Humanitarian Intervention (New York: New York University Press, 2006), pp. 84-116; and Jennifer M. Welsh, "Who Should Act? Collective Responsibility and the Responsibility to Protect," in W. Andy Knight and Frazer Egerton, eds., The Routledge Handbook of the Responsibility to Protect (New York: Routledge, 2012), pp. 103-14.

6 The main exceptions are Luke Glanville, Sharing Responsibility: The History and Future of Protection from Atrocities (Princeton, N.J.: Princeton University Press, 2021), esp. chap. 3; Kieran Oberman, "War and Poverty," Philosophical Studies 176 (2019), pp. 197-217; and James Pattison, "Opportunity Costs Pacifism," Law and Philosophy 39, no. 5 (2020), pp. 545-76.

7 "Populations at Risk," Global Centre for the Responsibility to Protect, n.d., www.globalr2p. org/populations-at-risk/.

8 See, for instance, Thomas Pogge, "An Institutional Approach to Humanitarian Intervention," Public Affairs Quarterly 6, no. 1 (1992), pp. 89-103. See also Roff, Global Justice, Kant and the Responsibility to Protect.

9 See, for instance, David Miller, National Responsibility and Global Justice (Oxford: Oxford University Press, 2007); and Thomas Nagel, "The Problem of Global Justice," Philosophy \& Public Affairs 33, no. 2 (2005), pp. 113-47.

${ }^{10}$ On various senses of imperfect duties and their application to the issue of mass atrocities, see Glanville, Sharing Responsibility.

${ }^{11}$ For examples of such scholarship, see n. 5 .

12 For examples of such accusations, see Mohammed Ayoob, "Humanitarian Intervention and State Sovereignty," International Journal of Human Rights 6, no. 1 (2002), pp. 81-102. For an excellent recent analysis, see Noele Crossley, "Conceptualising Consistency: Coherence, Principles, and the Practice of Human Protection," Global Responsibility to Protect 12, no. 4 (2020), pp. 440-63.

13 Thomas G. Weiss and Don Hubert, The Responsibility to Protect: Research, Bibliography, Background: Supplementary Volume to the Report of the International Commission on Intervention and State Sovereignty (Ottawa: International Development Research Centre, 2001), p. 149. 
${ }^{14}$ See, for example, the discussion in Anne-Marie Slaughter, "How the World Could—and Maybe Should -Intervene in Syria," Atlantic, January 23, 2012. Consider also Rajan Menon's remark that pragmatic selectivity in the application of $\mathrm{R}_{2} \mathrm{P}$ "cannot be squared with the universalistic commitment to human rights." Rajan Menon, The Conceit of Humanitarian Intervention (New York: Oxford University Press, 2016), p. 172.

15 Weiss and Hubert, Responsibility to Protect, p. 150.

${ }^{16}$ Bellamy and Luck, Responsibility to Protect, p. 42.

17 Ibid., p. 50.

18 "A Conversation with the UN Special Advisers on the Responsibility to Protect," Global Centre for the Responsibility to Protect, June 1, 2020, www.globalr2p.org/resources/a-conversation-with-the-un-specialadvisers-on-the-responsibility-to-protect/.

19 For ethical analysis of a range of nonmilitarist responses to the threat and perpetration of atrocities, see Cécile Fabre, Economic Statecraft: Human Rights, Sanctions, and Conditionality (Cambridge, Mass.: Harvard University Press, 2018); Michael Gross and Tamar Meisels, eds., Soft War: The Ethics of Unarmed Conflict (Cambridge, U.K.: Cambridge University Press, 2018); James Pattison, The Alternatives to War: From Sanctions to Nonviolence (Oxford: Oxford University Press, 2018); Lucia M. Rafanelli, "Promoting Justice Across Borders," Political Studies 69, no. 2 (2021), pp. 237-56; Lucia M. Rafanelli, Promoting Justice across Borders: The Ethics of Reform Intervention (Oxford: Oxford University Press, 2021).

${ }^{20}$ For instance, Dan W. Brock and Daniel Wikler, "Ethical Issues in Resource Allocation, Research, and New Product Development," in Dean T. Jamison, Joel G. Breman, Anthony R. Measham, George Alleyne, Mariam Claeson, David B. Evans, Prabhat Jha, Anne Mills, and Philip Musgrove, eds., Disease Control Priorities in Developing Countries, 2nd ed. (Washington, D.C.: World Bank, 2006), pp. 259-70; Bridget Pratt, Mark Sheehan, Nicola Barsdorf, and Adnan A. Hyder, "Exploring the Ethics of Global Health Research Priority-Setting," BMC Medical Ethics 19, no. 94 (2018); Jennifer Prah Ruger, "Global Health Justice," Public Health Ethics 2, no. 3 (2009), pp. 261-75; and Govind Persad, Alan Wertheimer, and Ezekiel J. Emanuel, "Principles for Allocation of Scarce Medical Interventions," Lancet 373, no. 9661 (2009), pp. 423-31.

${ }^{21}$ See, for instance, Lisa Fuller, "Priority-Setting in International Non-Governmental Organizations: It Is Not as Easy as ABCD," Journal of Global Ethics 8, no. 1 (2012), pp. 5-17; Thomas W. Pogge, "Moral Priorities for International Human Rights NGOs," in Daniel A. Bell and Jean-Marc Coicaud, eds., Ethics in Action: The Ethical Challenges of International Human Rights Nongovernmental Organizations (Cambridge, U.K.: Cambridge University Press, 2007), pp. 218-56; and Jennifer C. Rubenstein, Between Samaritans and States: The Political Ethics of Humanitarian INGOs (Oxford: Oxford University Press, 2015), pp. 143-70.

${ }^{22}$ See, for instance, "The Ethics of Refugee Prioritization: Reframing the Debate," ed. Kasper Lippert-Rasmussen and Annamari Vitikainen, special issue, Ethics \& Global Politics 13, no. 1 (2020).

${ }^{23}$ William MacAskill, Doing Good Better: How Effective Altruism Can Help You Make a Difference (London: Guardian Faber, 2015); Jennifer C. Rubenstein, "The Lessons of Effective Altruism," Ethics \& International Affairs 30, no. 4 (2016), pp. 511-26; and Peter Singer, The Most Good You Can Do: How Effective Altruism Is Changing Ideas about Living Ethically (New Haven, Conn.: Yale University Press, 2015).

${ }^{24}$ See, in particular, MacAskill, Doing Good Better.

25 Samuel Scheffler, "Doing and Allowing," Ethics 114, no. 2 (2004), pp. 215-39; Fiona Woollard, "The Doctrine of Doing and Allowing I: Analysis of the Doing/Allowing Distinction," Philosophy Compass 7, no. 7 (2012), pp. 448-58; and Fiona Woollard, "The Doctrine of Doing and Allowing II: The Moral Relevance of the Doing/Allowing Distinction," Philosophy Compass 7, no. 7 (2012), pp. 459-69.

${ }^{26}$ Ramesh Thakur, "R2P after Libya and Syria: Engaging Emerging Powers," Washington Quarterly 36, no. 2 (2013), pp. 61-76.

${ }^{27}$ For some related deliberations, see David Rodin, "Rethinking Responsibility to Protect: The Case for Human Sovereignty," in Don E. Scheid, ed., The Ethics of Armed Humanitarian Intervention (Cambridge, U.K.: Cambridge University Press, 2014), pp. 243-60, at pp. 258-60.

${ }^{28}$ In a somewhat similar vein, Chris Brown argues that practical judgment needs to be used when contemplating which situations to tackle. Practical judgment reflects on morally relevant considerations rather than an inflexible moral principle that prescribes inflexible courses of action. See Chris Brown, "Selective Humanitarianism: In Defense of Inconsistency," in Deen K. Chatterjee and Don E. Schied (eds), Ethics and Foreign Intervention (Cambridge, U.K.: Cambridge University Press, 2003), pp. 31-50.

${ }^{29}$ For further discussion, see Pattison, Alternatives to War. 
$3^{\circ}$ See, for instance, Toby Ord, The Moral Imperative toward Cost-Effectiveness in Global Health (Washington, D.C.: Center for Global Development, March 2013), www.cgdev.org/sites/default/files/ 1427016_file_moral_imperative_cost_effectiveness.pdf; and Pattison, "Opportunity Costs Pacifism."

${ }^{31}$ Pattison, "Opportunity Costs Pacifism."

${ }^{32}$ See, for instance, John J. Mearsheimer, "Bound to Fail: The Rise and Fall of the Liberal International Order," International Security 43, no. 4 (2019), pp. 7-50. For a more nuanced, more positive account, see Mette Eilstrup-Sangiovanni and Stephanie C. Hofmann, "Of the Contemporary Global Order, Crisis, and Change,” Journal of European Public Policy 27, no. 7 (2020), pp. 1077-89.

Abstract: Given the multiple threats of atrocities in the world at any given time, where should states direct their attention and resources? Despite the rich and extensive literature that has emerged on the responsibility to protect (RtoP), little thought has been given to the question of how states and other international actors should prioritize when faced with multiple situations of ongoing and potential atrocities. As part of the roundtable "The Responsibility to Protect in a Changing World Order: Twenty Years since Its Inception," in this essay we first demonstrate the importance of questions of prioritization for RtoP. We then delineate some of the issues involved in assessing the issue of prioritization, beginning with what we call the "basic maximization model," and introducing additional atrocity-specific and response-specific issues that also need to be considered. We also emphasize the importance of considering how the need to address mass atrocities should be weighed against other global responsibilities, such as those concerning global poverty, global health, and climate change. We thereby set an agenda for future discussions.

Keywords: mass atrocities, prioritization, responsibility, Responsibility to Protect (RtoP) 